Check for updates

Cite this: RSC Adv., 2017, 7, 33521

\title{
An optimized 3D carbon matrix for high rate silicon anodes $\uparrow$
}

\author{
Xuejun Bai, (D) *a Min Hou, ${ }^{\text {* }}$ Zhaoyu Yu, ${ }^{a}$ Chan Liu, ${ }^{a}$ Hui Cao, ${ }^{\text {ab }}$ Dong Wang ${ }^{\text {ab }}$ \\ and Junjie $\mathrm{Fu}^{\mathrm{c}}$
}

A free-standing 3D porous carbon matrix was fabricated by a solution-based self-assembly process, using graphene aerogel (GA) as the matrix and CNTs as the structural enhancer. CNTs, with high electrical conductivity and mechanical strength, formed into a 3D scaffold along with GA. Silicon particles, with an oxidation coating $\left(\mathrm{Si}\left(\mathrm{SiO}_{x}\right)\right.$, were embedded into this GA matrix, and twined around the CNTs to increase conductivity of the $\mathrm{Si}_{\mathrm{aSiO}}$ agglomerations and bonding force with the GA matrix. Electrodes constructed with the $\mathrm{Si} \mathrm{SSIO}_{x} / \mathrm{CNTs} / \mathrm{GA}$ containing $44 \mathrm{wt} \% \mathrm{SiaSiO}$ exhibit a stable storage capacity of $905 \mathrm{~mA} \mathrm{~h} \mathrm{~g}^{-1}$ at $4 \mathrm{~A} \mathrm{~g}^{-1}$ and $1500 \mathrm{~mA} \mathrm{~h} \mathrm{~g}^{-1}$ at $0.1 \mathrm{~A} \mathrm{~g}^{-1}$ after $150^{\text {th }}$ cycles with $93 \%$ capacity retention compared with the $10^{\text {th }}$ cycle capacity. These outstanding rate performances and cycling stability are attributed to the enhanced 3D porous matrix, which provides abundant internal space for volume changes of $\mathrm{SiaSiO}_{x}$ easy penetration of electrolyte, fast electron and ion transfer speed, and high mechanical strength.

Received 19th May 2017

Accepted 16th June 2017

DOI: $10.1039 / \mathrm{c} 7 \mathrm{ra0} 5647 \mathrm{~h}$

rsc.li/rsc-advances

matrixes, such as mesoporous carbon fiber, ordered hierar-

\section{Introduction}

For current commercial lithium-ion batteries (LIBs), graphite is used as an anode material with a $372 \mathrm{~mA} \mathrm{~h} \mathrm{~g}^{-1}$ theoretical capacity. ${ }^{1}$ The low energy density severely limits the applications of LIBs, especially in the automotive field. As a promising alternative, silicon ( $\mathrm{Si}$ ) has been considered as the leading anode material for next generation LIBs because of its high theoretical capacity of $\sim 4200 \mathrm{~mA} \mathrm{~h} \mathrm{~g}^{-1}$, high reserves in the earth, and low charge/discharge potential..$^{2-5}$ However, the large volumetric changes of $\mathrm{Si}(>300 \%)$, during $\mathrm{Li}^{+}$insertion/ extraction processes, lead to rapid capacity degradation, severe pulverization of the electrode, and destruction of the electrically conductive network. ${ }^{6-9}$ For better implementation of $\mathrm{Si}$ in LIBs, the introduction of a second phase as a conductive matrix is considered to obtain high stability Si based anodes, such as carbon-based matrices: amorphous carbon, ${ }^{\mathbf{1 0 - 1 4}}$ graphite, ${ }^{15}$ carbon fibers (CFs), ${ }^{\mathbf{1 6 - 1 9}}$ carbon nanotubes (CNTs), ${ }^{\mathbf{2 0}}$ and graphene. ${ }^{21-23} \mathrm{Si}$-graphene composites, such as grapheneencapsulated Si particles and Si-graphene nanosheets, show improved electrochemical performances due to their excellent electronic properties, flexibility, large specific surface area, good mechanical properties, and high thermal and chemical stability. ${ }^{\text {24-26 }}$ Particularly, the hierarchical porous carbon

\footnotetext{
${ }^{a}$ Shanghai Aerospace Power Technology Co., LTD, Shanghai, 201615, P. R. China. E-mail: renee1125@163.com

${ }^{b}$ Shanghai Institute of Space Power-sources, Shanghai, 200245, China

'Shanghai Geophysical Branch, Sinopec Offshore Oilfield Services Company, Shanghai, 201208, China

$\dagger$ Electronic supplementary information (ESI) available. See DOI: 10.1039/c7ra05647h
} chical carbon, and ordered mesoporous carbon, show better loading and fast $\mathrm{Li}^{+}$storage ability in LIBs. ${ }^{27-31}$ This hierarchical structure also shows positive influence in EDLC, electrochemical hydrogen storage, catalyst and other application area. $^{32-34}$ Graphene aerogel (GA) with 3D porous network structure has attracted much more attention, ${ }^{35-38}$ as it provides more micropores for electrolyte infiltration and free $\mathrm{Li}^{+}$diffusion. This increases rate capacity and power density of the LIBs in previous reports. ${ }^{39-41}$ However, it still remains challenging to future increase electron transport kinetics and overall mechanical strength.

In this work, CNTs, with ultra-high electrical conductivity, flexibility, and mechanical strength, had been uniformly employed in graphene oxide suspension via ultrasonic dispersion. In our previous work, we reported a technique to form $\mathrm{Si} @ \mathrm{SiO}_{x}$ core-shell nanoparticles by ozone treatment, which can improve dispersibility of Si nanoparticles in graphene oxide suspension. ${ }^{42}$ In the resulting free-standing $3 \mathrm{D}$ Si@SiO ${ }_{x} / \mathrm{CNTs}_{\text {GA }}$ composite, CNTs self-assembled into a 3D scaffold along GA and small $\mathrm{Si@SiO} x$ aggregation. Based on the enhanced stable-porous 3D matrix, Si@SiO $/$ CNTs/GA showed excellent storage capacity and cycling stability at high current density.

\section{Experimental}

\subsection{Sample preparation}

The Si@SiO ${ }_{x}$ nanoparticles with $4.2 \mathrm{~nm}$ oxidization layer were oxidized from Si nanoparticles ( $50 \mathrm{~nm}, 99.9 \%$, US Research Nanomaterials, Inc) at $200{ }^{\circ} \mathrm{C}$ as reported earlier. ${ }^{42}$ 
Typically, $\mathrm{Si@SiO}$. nanoparticles $(10,5,2.5 \mathrm{mg}$ respectively) and $10 \mathrm{mg}$ of CNTs (99.9\%, US Research Nanomaterials, Inc) were dispersed in $3 \mathrm{~mL}$ of ethanol and sonicated for $1 \mathrm{~h} .2 \mathrm{~mL}$ of GO suspension ( $5 \mathrm{mg} \mathrm{mL}^{-1}$ ) was added and sonicated for $1 \mathrm{~h}$ to obtain a stable suspension. $80 \mathrm{mg}$ of L-ascorbic acid (99\%, Sigma Aldrich) was then added to the suspension and sonicated for $20 \mathrm{~min}$ to dissolve the acid. This mixture was then kept at $80{ }^{\circ} \mathrm{C}$ for $8 \mathrm{~h}$ to initiate pre-reduction and the self-assembly process. The resulting solid was washed repeatedly with distilled deionized (DDI) water and then freeze-dried. Finally, the solid was heated at $800{ }^{\circ} \mathrm{C}$ in a flow of $\mathrm{Ar}$ for $2 \mathrm{~h}$ for further reduction of GO, to obtain the $\mathrm{Si@SiO} x / \mathrm{CNTs} / \mathrm{GA}$ composites ( $\mathrm{Si} @ \mathrm{SiO}_{x} / \mathrm{CNTs} / \mathrm{GA}-1,-2$, and -3 ). The process of fabrication the $\mathrm{Si} @ \mathrm{SiO}_{x} / \mathrm{CNTs} / \mathrm{GA}$ composite was shown in Fig. 1.

\subsection{Sample characterization}

X-ray diffraction (XRD) was carried out by a Rigaku D/max 2550 V X-ray diffractometer using Cu-K $\alpha$ irradiation. Raman spectrum was measured on a T64000 triple Raman system with a $514.5 \mathrm{~nm}$ Ar-ion laser. X-ray photoelectron spectroscopy (XPS) was conducted with Thermo Scientific ESCALAB 250Xi using Al $\mathrm{K} \alpha(1486.6 \mathrm{eV})$ excitation. Thermogravimetric analysis (TGA) was recorded on a Netzsh TG 209 F1 Analyzer, from room temperature to $800{ }^{\circ} \mathrm{C}$ with a ramp rate of $15^{\circ} \mathrm{C} \mathrm{min}{ }^{-1}$ in $15 \mathrm{~mL}$ $\min ^{-1}$ lab air. Microstructure images were collected using highresolution field emission scanning electron microscopy (FESEM, Hitachi SU8030). Cycled electrodes were removed from dissembled coin cells and rinsed in dimethyl carbonate (DMC) in an argon-filled glovebox before characterization by FESEM.

\subsection{Electrochemical measurements}

Electrochemical measurements were conducted at room temperature using CR2032 coin cells, with Li as the counter electrode and Celgard 2400 film as the separator. The $\mathrm{Si} @ \mathrm{SiO}_{x} /$ CNTs/GA composites, cut into circular discs of approximately 5 $\mathrm{mm}$ in diameter, were used as self-standing work electrodes. The electrolyte was $1 \mathrm{M} \mathrm{LiPF}_{6}$ in ethylene carbonate/dimethyl carbonate (EC/DMC $1: 1$ vol. ratio). The cells were assembled in an argon-filled glove box $\left(\mathrm{H}_{2} \mathrm{O}, \mathrm{O}_{2}<1 \mathrm{ppm}\right)$. Galvanostatic cycling measurements were performed with a BT2000 Potentiostat/Galvanostat system (Arbin Instruments) in the voltage range of 0.01-2 V. The current setting for cell tests and the specific capacity calculation were based on the total mass of Si@SiO $x /$ CNTs/GA composites. Cyclic voltammogram (CV), at

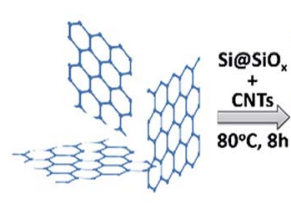

GO

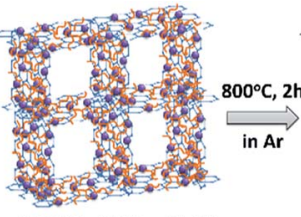

Si@SiO ${ }_{x} /$ CNTs with GA

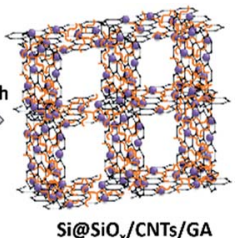

$\mathrm{Si}_{\mathrm{SiO}} / \mathrm{CNTs} / \mathrm{GA}$

$$
\text { - } \mathrm{Si}_{\mathrm{SiO}} \text { particles } \sim \mathrm{CNTS}
$$

Fig. 1 Schematic illustration of procedure to fabricate $\mathrm{SiaSiO} / \mathrm{CNTS} /$ GA composites. a scan rate of $0.1 \mathrm{mV} \mathrm{s}^{-1}$ within $2-0.01 \mathrm{~V}$, and EIS, at frequency $10^{6}-0.01 \mathrm{~Hz}$, were recorded by electrochemical workstation (Autolab PGSTAT128N).

\section{Results and discussion}

X-ray diffraction pattern of CNTs and Si@SiO ${ }_{x} / \mathrm{CNTs} / \mathrm{GA}-1$ are compared in Fig. 2a. The marked peaks are corresponded to crystalline $\mathrm{Si}$, suggesting the $\mathrm{Si}$ structure is preserved in the whole synthesis process. The peak of GO at $12^{\circ}$ isn't observable, and is replaced by a broader peak at $\sim 25.8^{\circ},{ }^{43,44}$ which overlaps with the sharp peak of CNTs. The Raman spectrum of $\mathrm{Si}_{\mathrm{SiO}_{x}}$ CNTs/GA-1 (Fig. 2b) shows five peaks clearly. A D-band at 1332 $\mathrm{cm}^{-1}$ indicates presence of disordered carbon, and a G-band at $1594 \mathrm{~cm}^{-1}$ and a 2D-band at $\sim 2880 \mathrm{~cm}^{-1}$ assign to the strong tangential mode of graphitized structure..$^{45}$ LA-band and TOband below $500 \mathrm{~cm}^{-1}$ are related to $\mathrm{Si}^{46}$ In $\mathrm{C}$ 1s XPS spectra (Fig. 2c), there are three peaks: two weak peaks at $286.2 \mathrm{eV}$ and $287.5 \mathrm{eV}$, representing $\mathrm{O}-\mathrm{C}-\mathrm{O} / \mathrm{C}-\mathrm{O}$ and $\mathrm{O}-\mathrm{C}=\mathrm{O}$ moiety respectively, and an intense peak at $284.8 \mathrm{eV}$ which represents the $\mathrm{C} / \mathrm{C}$ moiety. ${ }^{47}$ All the data above show CNTs/GA matrix is partially graphitized which can facilitate the electron transfer during electrochemical reactions. Three peaks in XPS Si 2p spectra (Fig. 2d) indicate of presence of three valence states of Si: $\mathrm{Si}^{4+}, \mathrm{Si}^{2+}$, and $\mathrm{Si}^{0}{ }^{48}$ The contents are $41 \%, 11 \%$, and $48 \%$. $\mathrm{SiO}_{x}$ shell around $\mathrm{Si}$ helps improve dispersibility and structure stability in GA.

The contents of $\mathrm{Si} @ \mathrm{SiO}_{x}$ in these composites were determined by TGA, shown in Fig. 3. As the crystal structure of Si@SiO ${ }_{x}$ is relative stable during TGA test, as shown in Fig. S1. $\dagger$ From the remaining weight after heating above $700{ }^{\circ} \mathrm{C}$, the $\mathrm{Si} @ \mathrm{SiO}_{x}$ loading in samples $\mathrm{Si} @ \mathrm{SiO}_{x} / \mathrm{CNTs} / \mathrm{GA}-1,-2$, and -3 were determined to be $44 \mathrm{wt} \%, 29 \mathrm{wt} \%$, and $20 \mathrm{wt} \%$ respectively. $\mathrm{Si@SiO} / \mathrm{CNTs} / \mathrm{GA}$ composites with different $\mathrm{Si} @ \mathrm{SiO}_{x}$ contents have similar 3D network structures (Fig. 4). The interconnecting micropores are open cells in nature, bounded by walls of
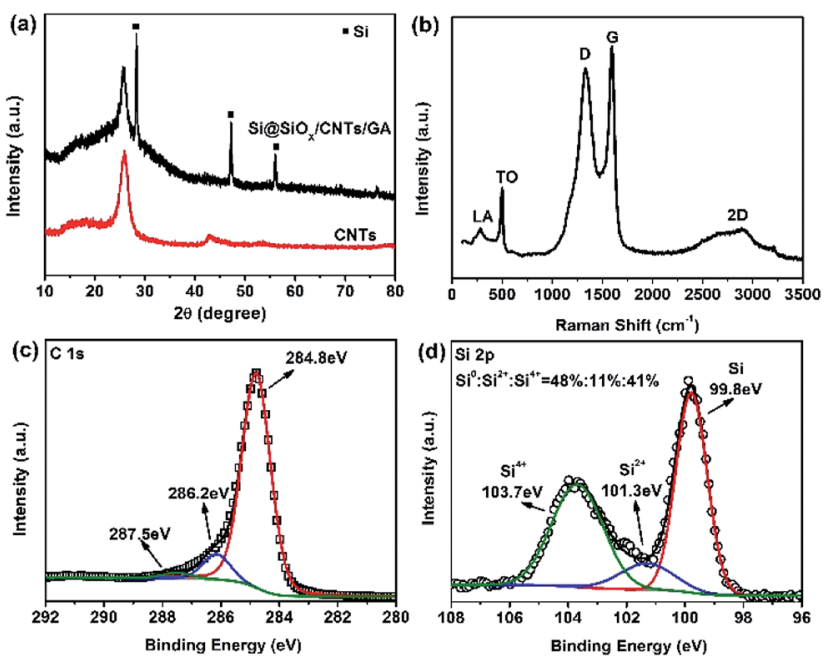

Fig. 2 (a) XRD patterns of CNTs and $\mathrm{SiaSiO}{ }_{x} / \mathrm{CNTs} / \mathrm{GA}-1$; (b, $c$ and d) Raman spectrum, high resolution $C$ 1s XPS spectra, and Si $2 p$ XPS spectra of $\mathrm{Si} \mathrm{SSiO}_{x} / \mathrm{CNTs} / \mathrm{GA}-1$, respectively. 


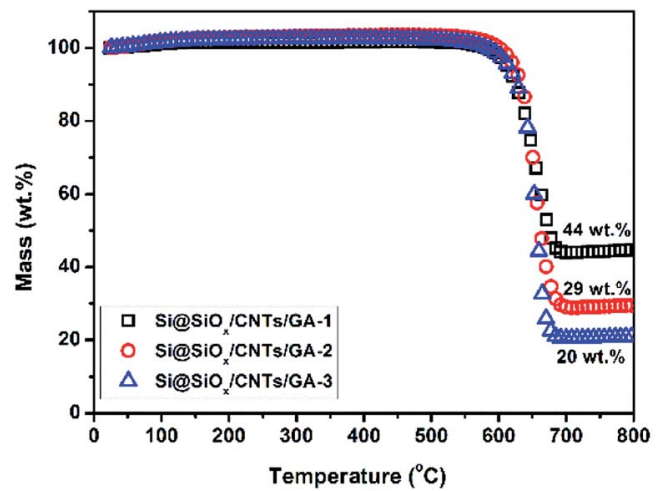

Fig. 3 TGA curves of $\mathrm{SiCSiO}_{x} / \mathrm{CNTS} / \mathrm{GA}$ composites.

ultrathin layers of stacked graphene sheets. CNTs are uniformly distributed on graphene sheet, forming a conductive flexible framework to support GA as a scaffold. The overall dispersion of $\mathrm{Si}_{\mathrm{SiO}}$ nanoparticles in GA has been great improved by oxidization layer, but small agglomerations also exist. As the $\mathrm{SiO}_{x}$ layer form hydrogen bonds ( $\mathrm{Si}-\mathrm{O}-\mathrm{H}-\mathrm{O}-\mathrm{C}$ ) with organic groups on GO. GO anchored with $\mathrm{Si}_{3} \mathrm{SiO}_{x}$ nanoparticles acted as a building block and self-assembled into a 3D network, driven by $\pi-\pi$ stacking interactions. Then during reduction, the $\mathrm{Si} \mathrm{SiO}_{x}$ nanoparticles can be anchored tightly and uniformly in GA. ${ }^{35,49}$ Some CNTs twine around $\mathrm{Si} @ \mathrm{SiO}_{x}$ nanoparticles to increase conductivity of $\mathrm{Si}_{0} \mathrm{SiO}_{x}$ agglomerations and bonding
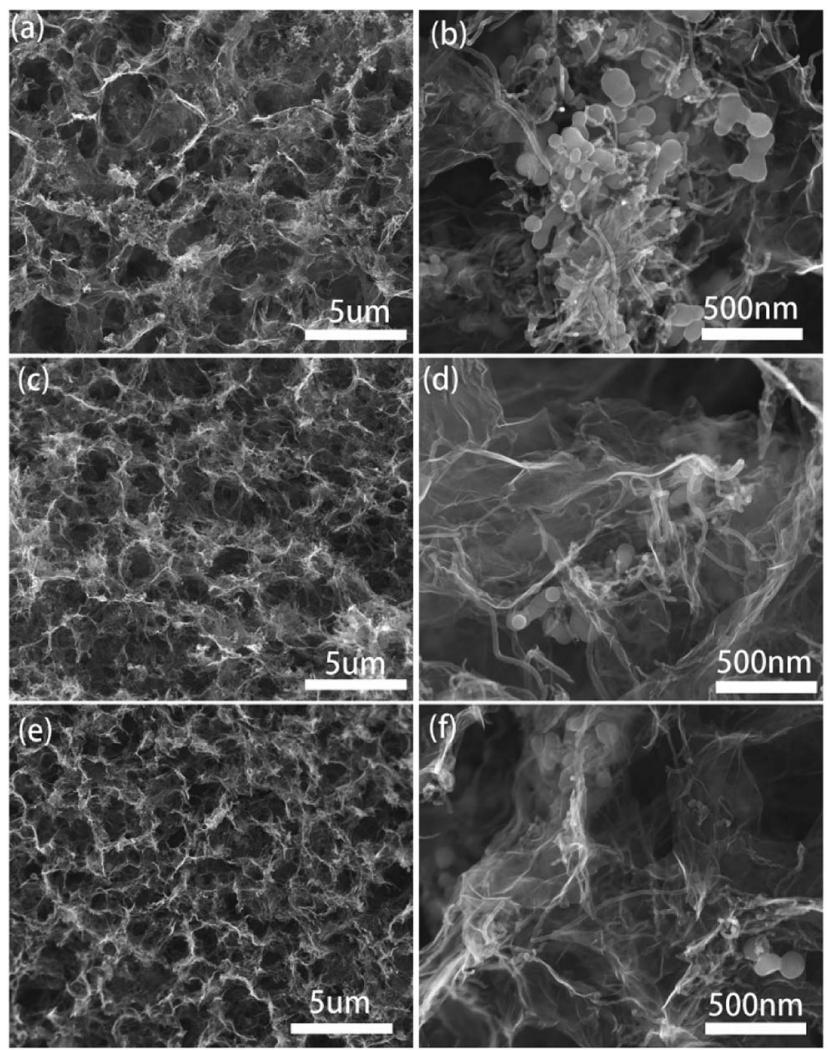

Fig. 4 SEM images of $\mathrm{SiCSiO}_{x} / \mathrm{CNTS} / \mathrm{GA}$ composites: (a, b) Si@SiO${ }_{x} /$ CNTs/GA-1, (c, d) $\mathrm{Si}^{\circ} \mathrm{SiO}_{x} / \mathrm{CNTs} / \mathrm{GA}-2$, (e, f) $\mathrm{Si} \mathrm{CSiO}_{x} / \mathrm{CNTs} / \mathrm{GA}-3$. force with GA matrix. The EDS spectra of $\mathrm{Si}_{0} \mathrm{SiO}_{x} / \mathrm{CNTs} / \mathrm{GA}-1$ is shown in Fig. S2. $\dagger$

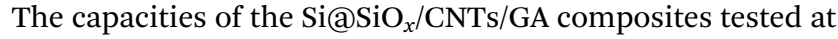
different current densities $\left(0.1,0.5,1,2\right.$, and $\left.4 \mathrm{~A} \mathrm{~g}^{-1}\right)$ are shown in Fig. 5a. The initial coulombic efficiencies of $\mathrm{Si}_{0} \mathrm{SiO}_{x} / \mathrm{CNTs} /$ GA $-1,-2$, and -3 are $57 \%, 60 \%$, and $62 \%$. The large initial capacity loss is mainly due to the formation of SEI film on the surface of porous CNTs/GA matrix and stable products of $\mathrm{Li}^{+}$ with $\mathrm{SiO}_{x}$ during lithiation. The increase of $\mathrm{Si}_{\mathrm{SiO}}$ loading doesn't show obvious effects on the cyclic stability, which shows that the hierarchical porous 3D structure of GA could effectively accommodate drastic volumetric variation of $\mathrm{Si}_{0} \mathrm{SiO}_{x}$ during cycling. ${ }^{50}$ Compared to the capacity of $1613 \mathrm{~mA} \mathrm{~h} \mathrm{~g}^{-1}$ at $10^{\text {th }}$ cycles at $0.1 \mathrm{~A} \mathrm{~g}^{-1}$, the capacity at $150^{\text {th }}$ cycles reaches $1504 \mathrm{~mA} \mathrm{~h}$ $\mathrm{g}^{-1}$ with $93 \%$ capacity retention. The cyclic stability of $\mathrm{Si}_{0} \mathrm{SiO}_{x}$ particles has been improved a lot (Fig. S3†). As the rate capacity retention shown in Fig. 5b, the capacities of $\mathrm{Si}_{0} \mathrm{SiO}_{x} / \mathrm{CNTs} / \mathrm{GA}-$ 1 are $1705 \mathrm{~mA} \mathrm{~h} \mathrm{~g}^{-1}$ at $0.1 \mathrm{Ag}^{-1}$ and $905 \mathrm{~mA} \mathrm{~h} \mathrm{~g}^{-1}$ at $4 \mathrm{Ag}^{-1}$, and the rate capacity retention at $4 \mathrm{~A} \mathrm{~g}^{-1}$ is $53 \%$. The rate capacity retention of $\mathrm{Si} @ \mathrm{SiO}_{x} / \mathrm{CNTs} / \mathrm{GA}$ is much better than that of $\mathrm{Si} @ \mathrm{SiO}_{x} / \mathrm{GA}$ (with similar $\mathrm{Si}_{0} \mathrm{SiO}_{x}$ content) shown in previous research. ${ }^{42}$ CNTs improve flexibility and conductivity of GA matrix, maximizing electron transmission speed. They also increase the bonding force between $\mathrm{Si}_{0} \mathrm{SiO}_{x}$ and GA, minimizing detachment of $\mathrm{Si}_{0} \mathrm{SiO}_{x}$ from GA.

The discharge-charge curves for $\mathrm{Si} @ \mathrm{SiO}_{x} / \mathrm{CNTs} / \mathrm{GA}-1$ (Fig. 5c) show the typical behavior of Si. The increase of current density shows little effects on the shape of these curves. The discharge plateaus are stable below $0.5 \mathrm{~V}$, and charge ranges appear between 0.3 and $0.6 \mathrm{~V}$. The electrode polarization doesn't increase obviously with current density. EIS of $\mathrm{Si}_{\mathrm{SiO}} /$ CNTs/GA-1 at initial state and post-cycle are shown in Fig. 5d. The Nyquist plots are fitted through the use of an equivalent
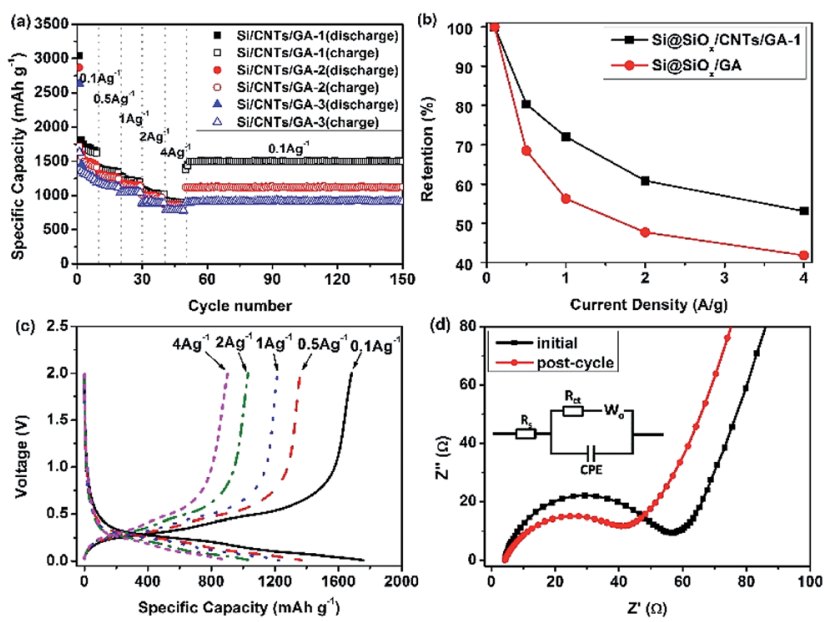

Fig. 5 (a) Rate cyclic performance of SiaSiO ${ }_{x} / \mathrm{CNTs} /$ GA composites, (b) capacity retention at different current densities of $\mathrm{Si} \mathrm{aSiO}_{x} / \mathrm{CNTs} /$ GA-1 and $\mathrm{Si} \mathrm{SSiO}_{x} / \mathrm{GA}$ composite, (c) galvanostatic charge-discharge profiles of $\mathrm{SiaSiO}{ }_{x} / \mathrm{GA}-1$ at various current densities as marked, and (d) the electrochemical impedance spectra of $\mathrm{Si}_{\mathrm{aSiO}} / \mathrm{CNTs} / \mathrm{GA}-1$ composites at initial state and post-cycle. The insert is the equivalent circuit used for the analysis. 
Table 1 EIS fitting results of $\mathrm{Si} \mathrm{SSiO}_{x} / \mathrm{CNTs} / \mathrm{GA}-1$ electrodes

\begin{tabular}{|c|c|c|c|c|c|}
\hline Sample & State & $R_{\mathrm{s}}(\Omega)$ & CPE- $T$ & CPE-P & $R_{\mathrm{ct}}(\Omega)$ \\
\hline $\mathrm{Si} @ \mathrm{SiO}_{x} / \mathrm{GA}-1$ & Initial & 4.6 & 0.00015 & 0.7641 & 49 \\
\hline $\mathrm{Si} @ \mathrm{SiO}_{x} / \mathrm{GA}-1$ & Post-cycle & 4.2 & 0.00014 & 0.7868 & 32.3 \\
\hline
\end{tabular}
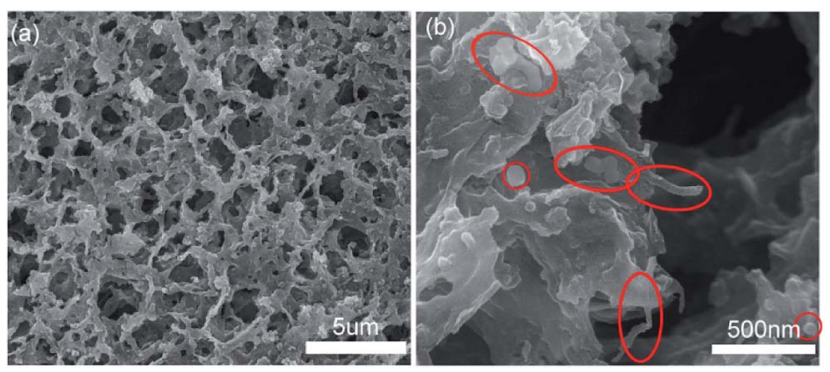

Fig. 6 SEM images of $\mathrm{Si} \mathrm{SSiO}_{x} / \mathrm{CNTs} / \mathrm{GA}-1$ anode after rate cycles test.

circuit (Fig. 5d insert). The semicircle in the high-frequency region is associated with charge transfer impedance $\left(R_{\mathrm{ct}}\right)$ and constant phase element of the electrode/electrolyte interface (CPE). The line in the low-frequency region is the Warburg impedance $\left(W_{\mathrm{o}}\right)$, which is related to the diffusion of $\mathrm{Li}^{+}$into the bulk of the electrode. The fitting data shows in Table $1 . R_{\mathrm{S}}$ is very low, indicating good electrical conductivity of $\mathrm{Si@SiO} / \mathrm{CNTs} /$ GA-1 during rate cycle test. $R_{\mathrm{ct}}$ decreases after the $150^{\text {th }}$ rate cycle, demonstrating better electrolyte infiltration and faster $\mathrm{Li}^{+}$ transfer speed..$^{35,51,52}$ This is consistent with excellent rate cyclic performance of these composites.

The structure stability of $\mathrm{Si} @ \mathrm{SiO}_{x} / \mathrm{CNTs} / \mathrm{GA}$ composite is further studied by post-cycling SEM images of $\mathrm{Si} @ \mathrm{SiO}_{x} / \mathrm{CNTs} /$ GA-1 electrode (Fig. 6). The electrode retains similar original porous 3-D structure as Fig. 3a. The pore size is still same, but graphene wall is thicker. No crack and damage can be found. $\mathrm{Si} \mathrm{SiO}_{x}$ nanoparticles and CNTs show no sign of additional agglomeration post-cycling, marked by red-circles in Fig. $6 \mathrm{~b}$. With supports of CNTs, GA shows improved elasticity and stability during lithiation/de-lithiation of $\mathrm{Si}_{0} \mathrm{SiO}_{x}$ nanoparticles.

\section{Conclusions}

A 3D porous carbon matrix was fabricated successfully via a solution-based self-assembly process and applied in anodes of LIBs. In this matrix, the interconnecting micropores are open cells in nature, bounded by walls of ultrathin layers of stacked graphene sheets. CNTs formed a conductive flexible scaffold supporting GA to strengthen overall mechanical properties. CNTs/GA matrix provided large specific surface areas for efficient loading of $\mathrm{Si}_{\mathrm{S}} \mathrm{SiO}_{x}$ nanoparticles. The abundant micropores effectively enhanced electrolyte infiltrate, $\mathrm{Li}^{+}$diffusion, and electron transport kinetics. They also provided enough space to accommodate volume changes of $\mathrm{Si}$ during $\mathrm{Li}^{+}$ insertion/extraction processes. Electrodes constructed with $\mathrm{Si} @ \mathrm{SiO}_{x} / \mathrm{CNTs} / \mathrm{GA}$ composites showed excellent outstanding rate capability $\left(1705 \mathrm{~mA} \mathrm{~h} \mathrm{~g}^{-1}\right.$ at $0.1 \mathrm{Ag}^{-1}$, and $905 \mathrm{~mA} \mathrm{~h}^{-1}$ at 4
$\mathrm{A} \mathrm{g}^{-1}$ ) and good cyclic stability (93\% capacity retention between $10^{\text {th }}$ and $150^{\text {th }}$ cycles at $\left.0.1 \mathrm{~A} \mathrm{~g}^{-1}\right)$. The outstanding results provide an optimized structural design and a promising modification method of carbon matrixes for high rate LIBs.

\section{Acknowledgements}

This work was supported by Shanghai Pujiang Program 17PJ1430100, Program of Shanghai Technology Research Leader 17XD1420600, Shanghai Science and Technology Innovation Action Plan 15DZ1201001 and 16111106001, Minhang District Leader. Assistance from the research groups of Prof. Harold H. Kung, Prof. Jiaxing Huang and Prof. Samuel Stupp of Northwestern University for parts of the tests was acknowledged.

\section{Notes and references}

1 J. M. Tarascon and M. Armand, Nature, 2001, 414, 359-367.

2 T. Kim, Y. H. Mo, K. S. Nahm and S. M. Oh, J. Power Sources, 2006, 162, 1275-1281.

3 H. Ma, F. Y. Cheng, J. Chen, J. Z. Zhao, C. S. Li, Z. L. Tao and J. Liang, Adv. Mater., 2007, 19, 4067-4070.

4 H. Kim and J. Cho, Nano Lett., 2008, 8, 3688-3691.

5 H. Tao, L. Fan and X. Qu, Electrochim. Acta, 2012, 71, 194200.

6 A. M. Wilson, B. M. Way, J. R. Dahn and T. Vanbuuren, J. Appl. Phys., 1995, 77, 2363-2369.

7 B. C. Kim, H. Uono, T. Sato, T. Fuse, T. Ishihara and M. Senna, Solid State Ionics, 2004, 172, 33-37.

8 C. Ma, C. Ma, J. Wang, H. Wang, J. Shi, Y. Song, Q. Guo and L. Liu, Carbon, 2014, 72, 38-46.

9 X. Zhou, Y. Yin, L. Wan and Y. Guo, Adv. Energy Mater., 2012, 2, 1086-1090.

10 A. A. Arie, O. M. Vovk and J. K. Lee, J. Electrochem. Soc., 2010, 157, A660-A665.

11 Q. Si, K. Hanai, T. Ichikawa, A. Hirano, N. Imanishi, Y. Takeda and O. Yamamoto, J. Power Sources, 2010, 195, 1720-1725.

12 J. Xie, N. Imanishi, T. Zhang, A. Hirano, Y. Takeda and O. Yamamoto, Mater. Chem. Phys., 2010, 120, 421-425.

13 J. Liu, N. Li, M. D. Goodman, H. Zhang, E. Epstein, B. Huang, Z. Pan, J. Kim, J. Choi, X. Huang, J. Liu, K. J. Hsia, S. J. Dillon and P. V. Braun, ACS Nano, 2015, 9, 1985-1994.

14 W. Li, Y. Tang, W. Kang, Z. Zhang, X. Yang, Y. Zhu, W. Zhang and C. S. Lee, Small, 2015, 11, 1345-1351.

15 I. Saleh and R. Raj, J. Power Sources, 2016, 310, 18-25.

16 A. Magasinski, P. Dixon, B. Hertzberg, A. Kvit, J. Ayala and G. Yushin, Nat. Mater., 2010, 9, 353-358.

17 S. M. Jang, J. Miyawaki, M. Tsuji, I. Mochida and S. H. Yoon, Carbon, 2009, 47, 3383-3391.

18 H. Liu, W. Qiao, L. Zhan and L. Ling, New Carbon Mater., 2009, 24, 124-130.

19 L. Wang, C. X. Ding, L. C. Zhang, H. W. Xu, D. W. Zhang, T. Cheng and C. H. Chen, J. Power Sources, 2010, 195, 5052-5056.

20 W. Wang and P. N. Kumta, ACS Nano, 2010, 4, 2233-2241. 
21 S. Chou, J. Wang, M. Choucair, H. Liu, J. A. Stride and S. Dou, Electrochem. Commun., 2010, 12, 303-306.

22 J. K. Lee, K. B. Smith, C. M. Hayner and H. H. Kung, Chem. Commun., 2010, 46, 2025-2027.

23 C. Sun, Y. Deng, L. Wan, X. Qin and G. Chen, ACS Appl. Mater. Interfaces, 2014, 6, 11277-11285.

24 J. Luo, X. Zhao, J. Wu, H. Jang, H. H. Kung and J. Huang, J. Phys. Chem. Lett., 2012, 3, 1824-1829.

25 X. Zhao, C. M. Hayner, M. C. Kung and H. H. Kung, Adv. Energy Mater., 2011, 1, 1079-1084.

26 W. Zhang, P. Zuo, C. Chen, Y. Ma, X. Cheng, C. Du, Y. Gao and G. Yin, J. Power Sources, 2016, 312, 216-222.

27 L. Wang, C. Yang, S. Dou, S. Wang, J. Zhang, X. Gao, J. Ma and Y. Yu, Electrochim. Acta, 2016, 219, 592-603.

28 Y. Sha, X. Xu, L. Li, R. Cai and Z. Shao, J. Power Sources, 2016, 314, 18-27.

29 Y. Xing, Y. Wang, C. Zhou, S. Zhang and B. Fang, ACS Appl. Mater. Interfaces, 2014, 6, 2561-2567.

30 M. S. Kim, D. Bhattacharjya, B. Fang, D. S. Yang, T. S. Bae and J. S. Yu, Langmuir, 2013, 29, 6754-6761.

31 B. Fang, J. H. Kim, M. S. Kim and J. S. Yu, Acc. Chem. Res., 2013, 46, 1397-1406.

32 B. Fang, M. Kim, J. H. Kim and J. S. Yu, Langmuir, 2008, 24, 12068-12072.

33 B. Fang, J. H. Kim, M. S. Kim, A. Bonakdarpour, A. Lam, D. P. Wilkinson and J. S. Yu, J. Mater. Chem., 2012, 22, 19031-19038.

34 B. Fang, A. Bonakdarpour, M. S. Kim, J. H. Kim, D. P. Wilkinson and J. S. Yu, Microporous Mesoporous Mater., 2013, 182, 1-7.

35 R. Wang, C. Xu, J. Sun, L. Gao and H. Yao, ACS Appl. Mater. Interfaces, 2014, 6, 3427-3436.

36 X. Liu, J. S. Cui, J. B. Sun and X. Zhang, RSC Adv., 2014, 4, 22601-22605.
37 S. Lu, Y. Chen, X. Wu, Z. Wang and Y. Li, Sci. Rep., 2014, 4, 4629.

38 K. Han, J. Shen, C. M. Hayner, H. Ye, M. C. Kung and H. H. Kung, J. Power Sources, 2014, 251, 331-337.

39 R. Tian, Y. Zhang, Z. Chen, H. Duan, B. Xu, Y. Guo, H. Kang, H. Li and H. Liu, Sci. Rep., 2016, 6, 1-9.

40 L. Zhang, Z. Wang, H. Wang, K. Yang, L. Wang, X. Li, Y. Zhang and H. Dong, J. Alloys Compd., 2016, 656, 278-283.

41 Y. Zhang, H. Liu, Z. Zhu, K. W. Wong, R. Mi, J. Mei and W. M. Lau, Methods Mol. Biol., 2016, 1336, 179-209.

42 X. Bai, Y. Yu, H. H. Kung, B. Wang and J. Jiang, J. Power Sources, 2016, 306, 42-48.

43 H. Xiang, K. Zhang, G. Ji, J. Y. Lee, C. Zou, X. Chen and J. Wu, Carbon, 2011, 49, 1787-1796.

44 J. Wang, C. Zhong, S. Chou and H. Liu, Electrochem. Commun., 2010, 12, 1467-1470.

45 B. Wang, X. Li, X. Zhang, B. Luo, M. Jin, M. Liang, S. A. Dayeh, S. T. Picraux and L. Zhi, ACS Nano, 2013, 7, 1437-1445.

46 J. Wu, X. Qin, H. Zhang, Y. He, B. Li, L. Ke, W. Lv, H. Du, Q. Yang and F. Kang, Carbon, 2015, 84, 434-443.

47 Y. Xu, Z. Lin, X. Huang, Y. Wang, Y. Huang and X. Duan, Adv. Mater., 2013, 25, 5779-5784.

48 X. Yuan, H. Xin, X. Qin, X. Li, Y. Liu and H. Guo, Electrochim. Acta, 2015, 155, 251-256.

49 Y. Teng, H. Zhao, Z. Zhang, Z. Li, Q. Xia, Y. Zhang, L. Zhao, X. Du, Z. Du, P. Lv and K. Swierczek, ACS Nano, 2016, 10, 8526-8535.

50 B. Fang, M. S. Kim, J. H. Kim, S. Lim and J. S. Yu, J. Mater. Chem., 2010, 20, 10253-10259.

51 D. Wang, J. Yang, X. Li, D. Geng, R. Li, M. Cai, T. K. Sham and X. Sun, Energy Environ. Sci., 2013, 6, 2900-2906.

52 C. Zhong, J. Wang, Z. Chen and H. Liu, J. Phys. Chem. C, 2011, 115, 25115-25120. 